\title{
EFFECTS OF A PROTEIC SWINE EXTRACT ASSOCIATED TO RECOVERY TREATMENT ON FUNCTIONAL INDEPENDENCE AND QUALITY OF LIFE IN PATIENTS POST STROKE
}

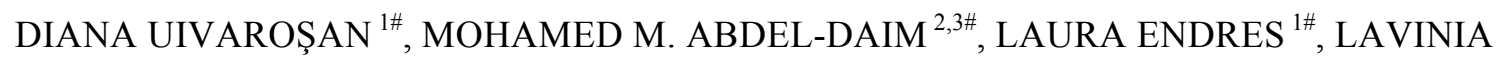 \\ PURZA $^{4,5 \#}$, CIPRIAN IOVAN $^{1 *} *$, SIMONA BUNGĂU ${ }^{5 \#}$, CRISTIAN GHEORGHE FURĂU ${ }^{6 \#}$, \\ DELIA MIRELA ŢIŢ ${ }^{5 \#}$
}

\author{
${ }^{1}$ University of Oradea, Faculty of Medicine and Pharmacy, Department of Preclinical Sciences, 10 P-ţa 1 Decembrie Street, \\ Oradea, Romania \\ ${ }^{2}$ Suez Canal University, Faculty of Veterinary Medicine, Pharmacology Department, Ismailia 41522, Egypt \\ ${ }^{3}$ Yokohama City University, Department of Ophthalmology and Micro-Technology, Yokohama, Japan \\ ${ }^{4}$ University of Oradea, Doctoral School of the University of Oradea, Department of Biomedical Sciences, 1 Universităţii Street, \\ Oradea, Romania \\ ${ }^{5}$ University of Oradea, Faculty of Medicine and Pharmacy, Pharmacy Department, 29 Nicolae Jiga Street, Oradea, Romania \\ ${ }^{6}$ Western University "Vasile Goldiş" of Arad, Faculty of Medicine, Department of Life Sciences, 86 L. Rebreanu Street, Arad, \\ Romania
}

*corresponding author:dr.iovan@biostandard.ro

\#All authors have equal contribution

Manuscript received: December 2017

\begin{abstract}
Stroke is one of the leading causes of mortality and morbidity worldwide. This study investigates the effect produced by associating a proteic swine extract (PSE) with classical recovery techniques on functional independence and quality of life of post-stroke patients. 139 patients that had suffered stroke were divided into 2 groups and were evaluated initially, at 6 and at 12 months. The FIM scale (Functional Independence Measure) and the SS-QoL scale (Stroke Specific Quality of Life Scale), were used to monitor the effects of therapy. There were no significant differences $(p>0.05)$ in the patients' evolution in terms of functional independence, but the effect size was more obvious in the group treated with PSE. The evolution of the quality of life was significantly better $(\mathrm{p}<0.05)$ after six months for patients who had PSE associated treatment. The results of this study provide a favourable evidence for the use of associated therapy of PSE and classical recovery procedures in patients who had suffered a stroke.
\end{abstract}

\section{Rezumat}

Accidentul vascular cerebral (AVC) reprezintă una dintre principalele cauze ale mortalității și morbidității la nivel mondial. Acest studiu investighează efectul produs prin asocierea unui hidrolizat proteic din creier de porcină (HPC) cu mijloacele de recuperare clasice asupra independenței funcționale şi a calităţii vieţii pacienţilor post AVC. 139 de pacienţi care au suferit AVC au fost împărţiţi în 2 loturi și au fost evaluați inițial, la 6 și la 12 luni. Scalele FIM (Functional Independence Measure) și SSC-QOL (Stroke Specific Quality of Life Scale) au fost utilizate pentru monitorizarea efectelor terapiei. Nu au existat diferenţe semnificative $(p>0,05)$ în evoluția pacienților în ceea ce privește independența funcțională, însă mărimea efectului a fost mai bună în lotul tratat cu HPC. Evoluția calității vieții a fost semnificativ mai bună $(p<0,05)$ la 6 luni, la pacienții care au avut HPC asociat în tratament. Rezultatele acestui studiu constituie o dovadă favorabilă pentru utilizarea terapiei asociate dintre HPC și procedurile clasice de recuperare la pacienţii care au suferit un AVC.

Keywords: proteic swine extract, cerebrovascular accident, stroke, medical recovery, quality of life

\section{Introduction}

Cerebrovascular accident (CVA) or stroke continues to represent a serious neurological condition that endangers thousands of people every year, being one of the leading causes of mortality and morbidity worldwide [8]. It is also an etiological factor for long-term disability installation, patients that survive stroke have often persistent symptoms such as balance deficiencies, perception deficiencies, aphasia, paralysis of some parts of the body, depression, and other alteration of the cognitive functions [16]. Because of this, stroke represents a major health problem, both in terms of high mortality and from sequelae perspective, with devastating effects on the quality of life of the patient and even of his family [14, 16, 20]. The current thrombolytic therapy for ischemic stroke is limited by the short window period of treatment, multiple contraindications and neurotoxic side effects [7]. Following a stroke, a number of deficiencies occur at the level of different systems, resulting in a complex 
invalidity structure. The mechanisms used to recover from these deficiencies are still only partly understood and elucidated. So far, there are no definitive methods, medicines, or exact treatment schemes in order to treat patients of the consequences of this disease [19]. Neurotrophic factors occupy a leading position in scientific research due to the theoretical importance and especially of the applicative perspective, the last decade being a step forward in the neurological research [15]. The best neuroprotective effects have been highlighted in cerebral ischemia, where neuronal death is slowed down by the administration of neurotrophic factors, leading to better functional recovery following ischemic stroke $[1,2,4]$. It has been demonstrated that the addition of proteic swine extract (PSE) to culture media has resulted in an increase in neuronal survival by stimulating synaptogenesis and sprouting [9]. Furthermore, at the frontal cortex and the hippocampus level, an important increase in the number of new cells and neurons was highlighted [17].

The current therapeutic approach to post-stroke rehabilitation implies that it is necessary to act in several directions, on finding some treatment schemes to include the use of multiple therapies in order to transform disabilities into abilities. The objective of this study was to investigate the effect of PSE therapy associated with recovery therapy, on the functional independence and on the quality of life of patients with stroke.

\section{Materials and Methods}

Study design

A total of 139 patients who have undergone stroke, hospitalized for recovery treatment at the Recovery Clinic Hospital of Băile Felix, Romania, and the Oradea Neurology Hospital, Romania during 2011 2014, were studied. The research was conducted in accordance with the WMA Declaration of Ethical Helsinki - Medical Research Involving Human Principles for Subjects and was approved by the Ethics Committee of the Medicine and Pharmacy Faculty, University of Oradea, Romania. All patients included in the study signed the informed consent, before enrolment. Patients were divided into two groups: the study group $(n=71)$ received PSE associated with balneophysiotherapy namely, the PSE + BFT group, and the control group $(n=68)$ that has only performed balneophysiotherapy namely, the BFT group. A prospective study was performed over a 12 months period, with patients being evaluated initially, at 6 months, and 12 months, respectively.

Proteic swine extract (PSE) administration

PSE was administered $10 \mathrm{~mL} /$ day, single dose, i.v., 10 days per month after dilution with physiological saline to a volume of $100 \mathrm{~mL}$, for one year [19].

\section{Associated medication allowed}

Because hypertension is one of the major risk factors for stroke and neuronal damage, special attention on blood pressure control was required, with target values below 140/90 $\mathrm{mmHg}$ but not under 120/60 $\mathrm{mmHg}$. All classes of antihypertensive medication were allowed, single or in combination, in recorded doses, adapted to each patient individually. There were also allowed antidiabetics, antibiotics, in pre-established doses; hydro-electrolytic and acid-base rebalancing, general treatment of stroke, including for thrombolytic cases. Associated medication prohibited

Some medications or drug classes associations were avoided during the study, as follows: simultaneous treatment with other neuro-protectors, except for those acting peripherally (amantadine, diazepam, piracetam, cistoline), simultaneous treatment with preparations that act through blood vessel dilatation (nicergoline, pentoxifylline, vinpocetine, vincamine, Ginkgo biloba extract).

\section{Assessment of functional independence}

The FIM scale (Functional Independence Measure), a standardized measurement system, comprising 6 domains, has been used. The levels of functional independence are in a number of 7 on a decreasing scale (from 7 - completely independent and up to 1 completely dependent) [3]. The higher the score, the healthier the individual is, without dysfunctional phenomena.

Assessment of the quality of life

The SS-QoL scale (Stroke Specific Quality of Life Scale), a standardized method that allows the evaluation of the health related quality of life, (HRQoL), specific for patients with stroke has been used. The three areas assessed were: physical (energy, mobility, self-care, extremity functionality, speech, sight, work), mentally (mood, personality, thinking) and social (the role of the family, the social role) $[21,22]$.

\section{Statistical analysis}

There were calculated the averages, frequency ranges, standard deviations, statistical significance tests by the Student method ( $t$ test) and $\chi^{2}$. To measure sensitivity to change, we used the statistical calculation system "effect size" (ES).

The interpretation of ES was compiled, namely small $\mathrm{ES}=0.20$, medium $\mathrm{ES}=0.50$, and large $\mathrm{ES}=0.80$. $\mathrm{ES}$ is important in expressing the findings of a quantitative study because a p-value can identify if there is an effect, but cannot reveal its magnitude [8]. The expression of ES can be calculated by using the equation: $E S=\left(m_{1}-m_{2}\right) / s_{1}$, where ES - effect size; $\mathrm{m}_{1}$ - the average value of the initial score; $\mathrm{m}_{2}$ - the average score value after a determined period; $s_{1}$ - the standard deviation value of the initial score. 


\section{Results and Discussion}

\section{Patients' characteristics}

In terms of demographic and clinical characteristics, there were no significant differences $(p>0.05)$ between the two groups (Table I).

Table I

Demographic and clinical characteristics

\begin{tabular}{|c|c|c|c|c|}
\hline \multirow[t]{2}{*}{ Characteristics } & \multicolumn{2}{|c|}{$\begin{array}{c}\text { Study group } \\
\quad(\mathrm{n}=71)\end{array}$} & \multicolumn{2}{|c|}{$\begin{array}{c}\text { Control group } \\
(n=68)\end{array}$} \\
\hline & No. & $\%$ & No. & $\%$ \\
\hline \multicolumn{5}{|l|}{ Gender } \\
\hline Females & 35 & 49.30 & 33 & 48.53 \\
\hline Males & 36 & 50.70 & 35 & 51.47 \\
\hline Total & 71 & 100.00 & 68 & 100.00 \\
\hline \multicolumn{5}{|l|}{ Age } \\
\hline$<50$ years & 6 & 8.45 & 5 & 7.35 \\
\hline $50-65$ years & 29 & 40.85 & 29 & 42.65 \\
\hline$>65$ years & 36 & 50.70 & 34 & 50.00 \\
\hline Average & \multicolumn{2}{|c|}{$64.06 \pm 7.66$} & \multicolumn{2}{|c|}{$64.12 \pm 7.25$} \\
\hline \multicolumn{5}{|l|}{ Diagnostic } \\
\hline Ischemic stro & 49 & 69.01 & 45 & 66.18 \\
\hline Haemorrhagic stroke & 22 & 30.99 & 23 & 33.82 \\
\hline \multicolumn{5}{|c|}{ Location of hemiplegia } \\
\hline Global & 40 & 56.34 & 40 & 58.82 \\
\hline Left & 17 & 23.94 & 19 & 27.94 \\
\hline Right & 23 & 32.39 & 21 & 30.88 \\
\hline Facio-brachial & 25 & 35.21 & 24 & 35.29 \\
\hline Crural & 6 & 8.45 & 4 & 5.88 \\
\hline \multicolumn{5}{|c|}{ The type of motor deficit } \\
\hline Hemiparesis & 48 & 67.61 & 48 & 70.59 \\
\hline Hemiplegia & 23 & 32.39 & 20 & 29.41 \\
\hline \multicolumn{5}{|c|}{ Time since stroke occurred } \\
\hline$<1$ month & 1 & 5.56 & 7 & 10.29 \\
\hline $1-3$ months & 6 & 33.33 & 20 & 29.41 \\
\hline $3-6$ months & 11 & 61.11 & 41 & 60.29 \\
\hline Average (months) & \multicolumn{2}{|c|}{$3.44 \pm 1.26$} & \multicolumn{2}{|c|}{$3.35 \pm 1.34$} \\
\hline
\end{tabular}

Associated pathology

There are no significant differences between the PSE + BFT group and the BFT group in terms of associated pathology $(p>0.05)$ (Table II).

Table II

Distribution of cases according to associated pathology

\begin{tabular}{l|cccc}
\hline \multicolumn{1}{c}{ Pathology } & \multicolumn{3}{c}{ BFT + PSE } & \multicolumn{2}{c}{ BFT } \\
& $(\mathrm{n}=71)$ & $(\mathrm{n}=68)$ \\
\cline { 2 - 5 } & No. & $\%$ & No. & $\%$ \\
\hline Ischemic cardiomyopathy & 50 & 70.42 & 50 & 73.53 \\
Valvulopathy & 8 & 11.27 & 7 & 10.29 \\
Heart rhythm disturbances & 7 & 9.86 & 4 & 5.88 \\
Previous myocardial infarction & 3 & 4.23 & 4 & 5.88 \\
\hline PSE $=$ proteic swine extract; BFT $=$ balneophysiotherapy
\end{tabular}

\section{The effects of the treatment}

The effects of the recovery procedures

There were no significant differences between PSE + BFT group and BFT group in terms of recovery treatment $(\mathrm{p}>0.05)$ (Table III).

Table III

Distribution of cases according to recovery treatment Recovery procedures PSE + BFT group BFT group

\begin{tabular}{lcccc} 
& \multicolumn{2}{c}{$(\mathbf{n}=\mathbf{7 1 )}$} & \multicolumn{2}{c}{$(\mathbf{n}=\mathbf{6 8})$} \\
\cline { 2 - 5 } & No. & $\mathbf{\%}$ & No. & $\mathbf{\%}$ \\
\hline Kinetotherapy & 71 & 100.00 & 68 & 100.00 \\
\hline Hydrokinetotherapy & 37 & 52.11 & 37 & 54.41 \\
\hline Massage & 71 & 100.00 & 68 & 100.00 \\
\hline Electrotherapy & 51 & 71.83 & 50 & 73.53 \\
\hline Thermotherapy & 30 & 42.25 & 28 & 41.18 \\
\hline Magnetotherapy & 48 & 67.61 & 43 & 63.24 \\
\hline Cryotherapy & 15 & 21.13 & 12 & 17.65 \\
\hline Contrasting therapy & 20 & 28.17 & 16 & 23.53 \\
\hline Occupational therapy & 61 & 85.92 & 60 & 88.24 \\
\hline Psychotherapy & 20 & 28.17 & 21 & 30.88 \\
\hline PSE & & &
\end{tabular}

$\mathrm{PSE}=$ proteic swine extract; $\mathrm{BFT}=$ balneophysiotherapy

The evolution of functional independence - Functional Independence Measure (FIM) Scale

The evolution of the patients evaluated by FIM score was good in both groups. The effect size at 12 months from the initial evaluation was higher for the PSE + BFT group than for the BFT group, both in the motor domain ( $\mathrm{ES}=2.23$, and $\mathrm{ES}=2.18$, respectively) and cognitive-behavioural $(\mathrm{ES}=1.50, \mathrm{ES}=1.42)$, but without significant differences ( $p>0.05)$ (Table IV).

Table IV

Evolution of the FIM score

\begin{tabular}{lccccc}
\hline \multicolumn{1}{c}{ Evaluated score } & Initial & At 6 months & ES 6 months & At 12 months & ES 12 months \\
\hline & \multicolumn{5}{c}{ PSE + BFT group $(\mathrm{n}=71)$} \\
\hline Motor score & $58.22 \pm 6.88$ & $66.12 \pm 7.01$ & 1.15 & $73.56 \pm 7.22$ & 2.23 \\
Cognition score & $28.12 \pm 3.02$ & $30.86 \pm 2.92$ & 0.91 & $32.66 \pm 3.12$ & 1.50 \\
Total score & $86.34 \pm 8.68$ & $96.98 \pm 9.12$ & 1.23 & $106.22 \pm 9.41$ & 2.29 \\
\hline \multicolumn{5}{c}{ BFT group $(\mathrm{n}=68)$} & \\
\hline Motor score & $59.12 \pm 6.37$ & $66.08 \pm 6.88$ & 1.09 & $73.02 \pm 7.18$ & 2.18 \\
Cognition score & $28.55 \pm 2.97$ & $30.85 \pm 3.12$ & 0.77 & $32.76 \pm 3.12$ & 1.42 \\
Total score & $87.67 \pm 8.68$ & $96.93 \pm 8.68$ & 1.07 & $105.78 \pm 10.22$ & 2.09 \\
\hline
\end{tabular}

Values are represented as Mean $\pm \mathrm{SD}(\mathrm{n}=71$ patients in study group; $\mathrm{n}=68$ patients control group); PSE = proteic swine extract; $\mathrm{BFT}=$ balneophysiotherapy; $\mathrm{ES}=$ effect size

The evolution of the quality of life-SS-QoL Scale Initially, there were no significant differences $(\mathrm{p}>0.05)$ between the scores of the studied groups, both on domains and on the total. Physical domain: Both at
6 and at 12 months, the evolution of the score did not show significant differences $(p>0.05)$ between the two groups. Compared to the initial value, the effect size was very good in both groups, with higher 
FARMACIA, 2018, Vol. 66, 5

effects being seen in the study group ( $\mathrm{ES}=1.67 \mathrm{vs}$. $\mathrm{ES}=1.22$ at 6 months, and $\mathrm{ES}=2.51$ vs. 2.27 at 12 months). Mental domain: At 6 months, the difference between the two groups becomes significant $(p<0.05)$, and at 12 months the difference is again insignificant $(p>0.05)$. Compared to the initial value, the effect size was very good in the PSE + BFT group, weaker in the BFT group at 6 months $(\mathrm{ES}=0.91 v s . \mathrm{ES}=0.37)$ and very good for both groups at 12 months (ES = $2.00 \mathrm{vs}$. 1.66). Social domain: At 6 and 12 months, the difference remains insignificant $(\mathrm{p}>0.05)$.

Compared to the initial value, the effect size was moderate in both groups at 6 months $(\mathrm{ES}=0.61 v \mathrm{~s}$. $\mathrm{ES}=0.47)$ and very good in both groups at 12 months $(\mathrm{ES}=1.14$ vs. 0.92) (Table V).

Table V

The evolution of SS-QOL score

\begin{tabular}{lccccc}
\hline \multicolumn{1}{c}{ Evaluated domain } & Initially & At 6 months & ES 6 month & At 12 months & ES 12 month \\
\hline \multicolumn{5}{c}{ PSE + BFT group $(\mathrm{n}=71)$} \\
\hline Physical & $102.27 \pm 13.11$ & $124.15 \pm 15.27$ & 1.67 & $135.22 \pm 16.03$ & 2.51 \\
Mental & $23.44 \pm 7.33$ & $30.12 \pm 8.16^{*}$ & 0.91 & $38.12 \pm 8.99$ & 2.00 \\
Social & $17.12 \pm 3.46$ & $19.22 \pm 3.71$ & 0.61 & $21.06 \pm 4.02$ & 1.14 \\
\hline Total & $\mathbf{1 4 2 . 8 3} \pm \mathbf{1 4 . 8 7}$ & $\mathbf{1 7 3 . 4 9} \pm \mathbf{1 5 . 5} *$ & $\mathbf{2 . 0 6}$ & $\mathbf{1 9 4 . 4 0} \pm \mathbf{1 6 . 2 8}$ & $\mathbf{3 . 4 7}$ \\
\hline \multicolumn{5}{c}{ BFT group $(\mathrm{n}=68)$} \\
\hline Physical & $103.51 \pm 12.87$ & $119.23 \pm 13.99$ & 1.22 & $132.78 \pm 17.03$ & 2.27 \\
Mental & $24.50 \pm 7.25$ & $27.20 \pm 7.56$ & 0.37 & $36.54 \pm 8.13$ & 1.66 \\
Social & $16.22 \pm 3.33$ & $17.78 \pm 3.78$ & 0.47 & $19.27 \pm 4.12$ & 0.92 \\
\hline Total & $\mathbf{1 4 4 . 2 3} \pm \mathbf{1 3 . 8 8}$ & $\mathbf{1 6 4 . 2 1} \pm \mathbf{1 4 . 0 7}$ & $\mathbf{1 . 4 4}$ & $\mathbf{1 8 8 . 5 9} \pm \mathbf{1 5 . 6 5}$ & $\mathbf{3 . 2 0}$
\end{tabular}

Values are represented as Mean $\pm \mathrm{SD}\left(\mathrm{n}=71\right.$ patients in study group; $\mathrm{n}=68$ patients control group); ${ }^{*} \mathrm{p}<0.05$ versus control group value $\mathrm{PSE}=$ proteic swine extract; $\mathrm{BFT}=$ balneophysiotherapy; $\mathrm{ES}=$ effect size.

SS-QoL total score: As for the SS-QoL total score, the difference became significant at 6 months $(\mathrm{p}<0.05)$ and at 12 months the difference reversed $(p>0.05)$. Compared to the initial value, the effect size on the quality of life was very good in both groups at 6 months $(\mathrm{ES}=2.06 v s . \mathrm{ES}=1.44)$ as well as at 12 months $(\mathrm{ES}=3.47$ vs. 3.20) (Table V).

In this study we attempted a combined approach between neuroprotection and recovery because the nature of the physio-pathological mechanisms and the link between these two categories are not fully elucidated. The results of this study indicate that the use of PSE as neurotrophic factor along with classical recovery techniques brings benefits in the post-stroke recovery process. PSE administration was associated with improved functional recovery in patients with severe and moderate disability after traumatic brain injury, respectively after stroke, in other studies as well $[11,15,18]$.

In a study on 146 patients, on improving the cognitive performance assessed on the Short Syndrome Test (SST) scale, there was highlighted a significant difference in the favour of PSE [12]. Other study performed on 1,069 patients, in 52 centres, treated with PSE, showed a $9 \%$ decrease in the mortality rate of the patients with moderate or severe ischemic stroke [10]. Some authors consider that an important aspect of neuroplasticity for recovery is that brainrelated changes take place depending on its use, from which we can conclude that active participation in the recovery programme ultimately leads to better functional reorganization at the cerebral level [5]. Moreover, this study demonstrates the importance of recovery treatment for patients with stroke, regardless of its type, the need for establishing an early treatment, prevention of sequelae and complications, obtaining a degree as high as possible for functional independence, faster and better socio-familial and professional integration. Previous studies showed that continued recovery after discharge, within the first year after stroke reduces functional deterioration of the patient and improves the quality of life [6, 13, 19].

Mureşanu et al [18] conducted prospective, randomized, placebo control trials to investigate the effects of PSE on patients with stroke. They compared PSE and placebo treatments for three months, including 208 patients in their study; 104 of them received PSE and 104 received placebo. Their conclusion was that PSE had safe and effective action on the global and functional outcome in the early rehabilitation of patients after stroke.

The importance of this study appears in the large number of participants which makes the study more relevant. Also, our data is consistent, precise, and reliable. This study is well-designed and the group is representative for the studied population. Besides, we determined the outcomes over a long period of time (12 months) which makes our data more reliable.

Following a stroke, a number of deficiencies occur across the different systems, resulting in a complex disability structure. The mechanisms used to recover from these deficiencies are still only partially understood and elucidated. So far, there are no definitive methods, medications, or exact treatment regimens to treat patients from the consequences of this pathology [19]. 


\section{Conclusions}

The results of this study provide favourable evidence for the use of classical recovery procedures and techniques associated with drug treatment, including PSE (a neurotrophic factor) in order to restore the health of patients who have suffered a stroke.

\section{Conflict of interests}

The authors declare no conflict of interest.

\section{References}

1. Amiri-Nikpour MR, Nazarbaghi S, AhmadiSalmasi B, Mokari T, Tahamtan U, Rezaei Y, Cerebrolysin effects on neurological outcomes and cerebral blood flow in acute ischemic stroke. Neuropsych Dis Treat., 2014; 10: 2299-2306.

2. Bornstein N, Poon WS, Accelerated recovery from acute brain injuries: clinical efficacy of neurotrophic treatment in stroke and traumatic brain injuries. Drugs Today, 2012; 48(Suppl A): 43-61.

3. Cavanagh SJ, Hogan K, Gordon V, Fairfax J, Strokespecific FIM models in an urban population. $J$ Neurosci Nurs., 2000; 32(1): 17-21.

4. Chen CC, Wei ST, Tsaia SC, Chen XX, Cho DY, Cerebrolysin enhances cognitive recovery of mild traumatic brain injury patients: double-blind, placebocontrolled, randomized study. Brit J Neurosurg., 2013; 27(6): 803-807.

5. Denti L, Agosti M, Franceschini M, Outcome predictors of rehabilitation for first stroke in the elderly. Eur J Phys Rehabil Med., 2008; 44(1): 3-11.

6. Diserens K, Michel P, Bogousslavsky J, Early mobilisation after stroke: Review of the literature. Cerebrovasc Dis., 2006; 22(2-3): 183-190.

7. Elmaraezy A, Abushouk AI, Saad S, Eltoomy M, Mahmoud O, Mahmoud H, Aboelmakarem HA, Fotoh AA, Althaher F, Huy NT, Desmoteplase for acute ischemic stroke: A systematic review and meta-analysis of RCTs. CNS Neurol Disord Drug Targets, 2017;16(7): 789-799.

8. Fodor K, Țiț DM, Paşca B, Buştea C, Uivaroșan D, Endres L, Iovan C, Abdel-Daim M, Bungău S, Long-term resveratrol supplementation as a secondary prophylaxis for stroke. Oxid Med Cell Longev., 2018; 2018: 1-10.

9. Hartbauer M, Hutter-Paier B, Skofitsch G, Windisch M, Antiapoptotic effects of the peptidergic drug cerebrolysin on primary cultures of embryonic chick cortical neurons. J Neural Transm., 2001; 108(4): 459-473.

10. Hong Z, Moessler H, Bornstein N, Brainin M, Heiss WD, CASTA-Investigators, A double-blind, placebo-controlled, randomized trial to evaluate the safety and efficacy of Cerebrolysin in patients with acute ischaemic stroke in Asia-CASTA. Int J Stroke, 2009; 4(5): 406-412.

11. Khalili H, Niakan A, Ghaffarpasand F, Effects of Cerebrolysin on functional recovery in patients with severe disability after traumatic brain injury: A historical cohort study. Clin Neurol Neurosurg., 2017; 152: 34-38.

12. Ladurner G, Kalvach P, Moessler H, Cerebrolysin Study Group Neuroprotective treatment with Cerebrolysin in patients with acute stroke: a randomised controlled trial. J Neural Transm., 2005; 112(3): 415-428.

13. Legg L, Langhorne P, Outpatient Service Trialists Rehabilitation therapy services for stroke patients living at home: systematic review of randomised trials. Lancet, 2004; 363(9406): 352-356.

14. Lopez-Bastida J, Oliva Moreno J, Worbes Cerezo M, Perestelo Perez L, Serrano-Aguilar P, MontónÁlvarez F, Social and economic costs and healthrelated quality of life in stroke survivors in the Canary Islands, Spain. BMC Health Serv Res., 2012; 12(1): 1-9.

15. Masliah E, Díez-Tejedor E, The pharmacology of neurotrophic treatment with Cerebrolysin: brain protection and repair to counteract pathologies of acute and chronic neurological disorders. Drugs Today, 2012; 48(SupplA): 3-24.

16. Mozaffarian D, Benjamin EJ, Go AS, Arnett DK, Blaha MJ, Cushman M, Heart Disease and Stroke Statistics - 2016 Update. Circulation, 2016; 133(4): e38-e360.

17. Mureşanu DF, Neuromodulation with pleiotropic and multimodal drugs - future approaches to treatment of neurological disorders. Acta Neurol Suppl., 2010; 106: 291-294.

18. Mureşanu DF, Heiss WD, Hoemberg V, Bajenaru O, Popescu CD, Vester JC, Rahlfs VW, Doppler E, Meier D, Moessler H, Guekht A, Cerebrolysin and recovery after stroke (CARS): A randomized, placebocontrolled, double-blind, multicenter trial. Stroke, 2016; 47(1): 151-159.

19. Onose G, Teoibaș-Șerban D, Popescu C, Andone I, Brumă E, Mihăescu A, Haras M, Bumbea AM, Anghelescu A, Spircu T, Badiu C, Daia C, New approaches regarding the use of Actovegin ${ }^{\circledR}$ in subacute/postacute/subchronic traumatic brain injury patients. Farmacia, 2017; 65(5): 772-777.

20. Uivaroşan D, The importance of neurotrophic medication associated with modern recovery techniques in stroke patients. $\mathrm{PhD}$ thesis, Oradea University, 2014.

21. Williams LS, Weinberger M, Harris LE, Clark DO, Biller J, Development of a stroke-specific quality of life scale. Stroke, 1999; 30(7): 1362-1369.

22. Williams LS, Weinberger M, Harris LE, Biller J, Measuring quality of life in a way that is meaningful to stroke patients. Neurology, 1999; 53(8): 1839-1843. 